Abstracta Iranica

Revue bibliographique pour le domaine irano-aryen

Volume 40-41 | 2019

Comptes rendus des publications de 2017-2018

\title{
Jan Tavernier. "The Functions of Abrupt Spellings in the Elamite Writing System"
}

\section{Salman Aliyari Babolghani}

\section{Q OpenEdition \\ 1 Journals}

\section{Electronic version}

URL: http://journals.openedition.org/abstractairanica/50576

DOI: 10.4000/abstractairanica.50576

ISBN: 1961-960X

ISSN: 1961-960X

Publisher:

CNRS (UMR 7528 Mondes iraniens et indiens), Éditions de l'IFRI

Electronic reference

Salman Aliyari Babolghani, "Jan Tavernier. "The Functions of Abrupt Spellings in the Elamite Writing System"'', Abstracta Iranica [Online], Volume 40-41 | 2019, document 8, Online since 30 December 2019, connection on 24 April 2021. URL: http://journals.openedition.org/abstractairanica/50576 ; DOI: https://doi.org/10.4000/abstractairanica.50576

This text was automatically generated on 24 April 2021.

Tous droits réservés 


\title{
Jan Tavernier. "The Functions of Abrupt Spellings in the Elamite Writing System"
}

\author{
Salman Aliyari Babolghani
}

\section{REFERENCES}

Jan Tavernier. "The Functions of Abrupt Spellings in the Elamite Writing System" in B. Mofidi-Nasrabadi, D. Prechel, A. Pruß (eds.). Elam and its Neighbors. Recent Research and New Perspectives. Proceedings of the International Congress Held at Johannes Gutenberg University Mainz, September 21-23, 2016. (Elamica 8), 2018, Hildesheim: Franzbecker, p. $137-151$

1 This article discusses the abrupt spellings (the type (C)VC-VC and also, as it appears from the treatment of the author, (C)VC-V) in the Elamite cuneiform writing system from the old up to the Achaemenid Elamite period and in various kinds of texts (administrative, royal and legal) in Elamite and also Akkadian language.

2 Tavernier identifies four functions for this kind of spelling: 1. to mark the boundary between two components of a compound, especially in proper names, e.g. Akkadian (in the Old Elamite period) A-in-un- $a k^{k i} / A^{\prime}$ in-Unak/ 'house of Unak'; Middle Elamite ${ }^{d} H u-\underline{b a n-}$ e-lu /Hupan-elu/ 'divine name'. 2. To distinguish the morpheme boundaries (i.e. roots

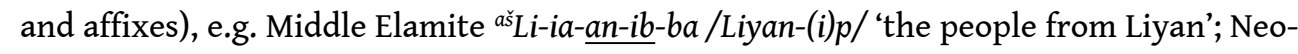
Elamite hi-ǐ̌s-e [/hiš-e/ 'his name']. 3. To indicate consonant clusters, especially in Achaemenid Elamite renderings of old Iranian forms, e.g. Achaemenid Elamite hal $\mathrm{Ha}-\underline{i k-}$ iš-ti-bar-ra /"Axštibara-/; hal Ba-ka-bu-ik-iš-šá /*Bagabuxša-/. 4. To indicate a phonetic complement, attested especially in the later periods, e.g. Neo-Elamite ${ }^{a \check{s}} \mathrm{~A}-a-p i{ }^{i}{ }_{-}-r a$; Achaemenid Elamite $h u-u t-\underline{t a s i \underline{s}-}-d a$. 
3 According to this research, the abrupt spellings are more often attested in Elamite texts than in Akkadian ones and occur more frequently in the later (i.e. Neo- and Achaemenid Elamite) periods.

\section{AUTHORS}

SALMAN ALIYARI BABOLGHANI

Iran 